\title{
EVALUASI KUALITAS INSTRUMEN PENGUKURAN KINERJA TENAGA PENDIDIK
}

\author{
Uswatun Hasanah ${ }^{1}$, Susilahudin Putrawangsa ${ }^{2},{ }^{3}$ Raden Fanny Printi Ardi \\ 1STMIK Bumigora Mataram, Jalan Ismail Marzuki Mataram, Indonesia \\ 2Universitas Islam Negeri Mataram, Jalan Pendidikan No 35 Mataram. Indonesia \\ ${ }_{3}^{3}$ STMIK Bumigora Mataram, Jalan Ismail Marzuki Mataram, Indonesia \\ 1uswatun@stmikbumigora.ac.id, 22susputrawangsa@gmail.com $\underline{3 \text { fanny.dlj@gmail.com }}$
}

\begin{abstract}
Abstrak
Kajian ini adalah analisis kualitas instrumen pengukuran kinerja tenaga pendidik yang digunakan di salah satu perguruan tinggi di Nusa Tenggara Barat. Kajian ini bertujuan untuk meningkatkan kualitas instrumen tersebut. Analisis ini dilakukan dengan metode Analisis Factor (Factor Analysis). Terdapat 3 faktor pengukuran yang terdapat dalam instrument tersebut, yaitu faktor pedagogik (5 indikator), profesionalisme (11 indikator) dan kepribadian (3 indikator). Berdasarkan hasil analisis data disimpulkan bahwa: 1) Indikator dalam instrumen tersebut dapat dikelompokkan menjadi dua faktor, yaitu faktor formal dan informal. Faktor formal bersifat institusional dan terstruktur, seperti indikator penyampaian pokok materi, penggunaan metode pembelajaran, pemberian contoh yang sesuai dengan materi ujian, dan penggunaan alat atau media pembelajaran. Sedangkan faktor informal bersifat noninstitusional yang cenderung lebih bersifat hubungan emosional atau tidak resmi, seperti kemampuan pendidik dalam menciptakan suasana yang nyaman dan bersahabat selama perkuliahan; 2) Pada instrumen tersebut, ditemukan sejumlah indikator yang perlu ditiadakan karena memiliki bobot indikator lebih kecil dari 0.5, seperti salah satu faktor profesionalisme, yaitu 'Dosen menjelaskan keterkaitan bidang/topik yang diajarkan dengan bidang/topik lain di luar mata kuliah'. Indikator ini perlu ditiadakan karena memiliki makna yang sama dengan indikator profesionalisme lainnya, yaitu 'Dosen menjelaskan penerapan bidang/topik yang diajarkan dengan kebutuhan dunia nyata'.
\end{abstract}

Kata kunci: Analisis Faktor; Evaluasi; Instrumen; Pengukuran Kinerja; Tenaga Pendidik

\begin{abstract}
The current research is an analysis on the quality of an instrument that is used to measure educator performance at a college in West Nusa Tenggara. The research aims to improve the quality of the instrument. Factor Analysis is used in the study. There are 3 measurement factors in the instrument, those are pedagogic factors (5 indicators), professionalism (11 indicators) and personality ( 3 indicators). The result shows that: 1 ) those indicators can be classified into two factors, formal factors and informal factors. Formal factors is institutional and structured, such as the indicators of subject matter delivery, the use of teaching method, the use of relevance example, and the use of learning media and tools. Meanwhile, informal factors is non-institutional, which tends to be emotional relationship or informal relationship, such as educators capability in creating pleasant and friendly classroom; 2) It is found that some indicators need to be removed
\end{abstract}


Hasanah, U., Putrawangsa, S., \& Ardi, R. (2017). EVALUASI KUALITAS INSTRUMEN PENGUKURAN KINERJA TENAGA PENDIDIK. JURNAL TATSQIF, 15(1). Retrieved from http://ejurnal.iainmataram.ac.id/ index.php/tatsqif/article/view/1310

\begin{abstract}
because they have indicator values less than 0.5 , for instance the indicator that 'lecturers explain the relationship between the subjects being taught and other subjects outside that subjects' is need to be removed because it has a similar meaning with another indicator that is 'lectures explain the application of the subject in real life'.
\end{abstract}

Keywords: Factor Analysis; Evaluation; Instrument; Performance Measurement; Educator

\title{
PENDAHULUAN
}

Setiap perguruan tinggi memiliki badan penjamin mutu yang bertugas untuk mengevaluasi semua kegiatannya berdasarkan standar SPMI. Standar SPMI merupakan dokumen tertulis berisi kriteria, patokan, spesifikasi mengenai sesuatu yang harus dicapai atau dipenuhi oleh suatu perguruan tinggi. Standar ini berdasarkan kebijakan atau pernyataan tertulis yang menjelaskan pemikiran, sikap, pandangan dari institusi tentang sesuatu hal. Oleh sebab itu, semua unit di dalam perguruan tinggi seperti lembaga, program studi, badan dan unit pelaksana teknis diatur dalam kebijakan SPMI-nya (Tim Penyusun STMIK Bumigora Mataram, 2015).

Demikian halnya dengan instrumen pengukur kinerja pendidik telah diatur dalam SPMI setiap perguruan tinggi. Misalnya, STMIK Bumigora Mataram menggunakan instrumen untuk mengukur kinerja para pendidik di lingkungannya yang terdiri atas pengukur Pedagogik, Profesionalisme dan Kepribadian. Hal ini sejalan dengan Peraturan Menteri Pendidikan Nasional Republik Indonesia Nomor 16 Tahun 2007 tentang Standar Kualifikasi Akademik dan Kompetensi Guru yaitu dikembangkan dengan 4 komponen utama seperti kompetensi pedagogik, kepribadian, soasial dan profesional. Keempat kompetensi tersebut terintegrasi dalam kinerja guru (Departemen Pendidikan Nasional, 2008).

Pendidik merupakan kebutuhan dasar yang bertujuan untuk meningkatkan kualitas sumber daya manusia sehingga tingkat pencapaian kehidupan yang semakin maju dan sejahtera. Oleh sebab itu, istilah pendidikan diatur dalam Undang-Undang No 20 tahun 2003 pasal 1 ayat 1 tentang Sistem Pendidikan Nasional menyebutkan bahwa pendidikan 
Hasanah, U., Putrawangsa, S., \& Ardi, R. (2017). EVALUASI KUALITAS INSTRUMEN PENGUKURAN KINERJA TENAGA PENDIDIK. JURNAL TATSQIF, 15(1). Retrieved from http://ejurnal.iainmataram.ac.id/ index.php/tatsqif/article/view/1310

merupakan usaha sadar dan terencana untuk mewujudkan susana belajar dan proses pembelajaran agar peserta didik secara aktif mengembangkan potensi dirinya untuk memiliki kekuatan spiritual keagamaan, pengendalian diri, kepribadian, kecerdasan, akhlak mulia serta keterampilan yang dimiliki dirinya, masyarakat, bangsa dan negara.

Untuk mencapai tujuan pendidikan nasional yang dijabarkan sebelumnya, maka ada beberapa yang harus dibenahi, salah satunya peran pendidik. Peran pendidik menentukan tinggi rendahnya mutu pendidikan, akan tetapi kinerja pendidik juga banyak dipengaruhi oleh beberapa faktor baik dari dalam maupun dari luar individu yang bersangkutan (Susanto, 2012). Hal ini yang mendasari kami untuk mengetahui kondisi kinerja pendidik yang dapat diamati dari faktor pengukur evaluasi instrumen kinerja.

Penilaian kinerja harus memenuhi standar tertentu yang sesuai dengan indikator kinerja sebagai alat ukur. Indikator penilaian kinerja adalah kualitas hasil kerja, ketepatan waktu menyelesaikan pekerjaan, inisiatif/prakarsa dalam menyelesaikan pekerjaan, kemampuan menyelesaikan pekerjaan dan komunikasi/kemampuan membina kerjasama dengan pihak lain (Mitchell, 1987). Oleh sebab itu, indikator kinerja pendidik yang terdapat pada SPMI STMIK Bumigora Mataram terdiri atas kompetensi pedagogik, profesionalisme dan kepribadian.

Kompetensi pedagogik sangat penting diukur dalam meningkatkan mutu kegiatan proses pembelajaran. Hal ini disebabkan karena kompetensi pedagogik merupakan salah satu jenis kompetensi yang mutlak perlu dikuasai oleh pendidik di tingkat dasar, menengah, maupun perguruan tinggi. Kompetensi pedagogik ditandai dengan kemampuan pendidik dalam mengelola pembelajaran peserta didik sehingga kompetensi ini sangat khas sehingga dapat membedakan pendidik dengan profesi lainnya dan menentukan tingkat keberhasilan proses dan hasil pembelajaran peserta didiknya. 
Hasanah, U., Putrawangsa, S., \& Ardi, R. (2017). EVALUASI KUALITAS INSTRUMEN PENGUKURAN KINERJA TENAGA PENDIDIK. JURNAL TATSQIF, 15(1). Retrieved from http://ejurnal.iainmataram.ac.id/ index.php/tatsqif/article/view/1310

Kompetensi profesionalisme dievaluasi untuk melihat kemampuan pendidik dalam menjalankan perannya secara optimal dalam menyiapkan karakter peserta didik yang sesuai dengan UU No 20 Tahun 2003 Bab II Pasal 3. Seorang pendidik yang profesional memiliki kemampuan dalam bidang mendidik sehingga dapat dikatakan sebagai orang yang terdidik, terlatih dan memiliki pengalaman yang luas dalam bidangnya. Oleh sebab itu, profesionalisme mensyaratkan pendidik untuk terampil berdasarkan konsep dan teori ilmu pengetahuan, ahli dalam bidangnya, adanya tingkat pendidikan keguruan yang memadai, peka terhadap dampak kemasyarakatan dan memiliki komitmen untuk melakukan transformasi pengetahuan dan pembentukan karakter (Kementerian Pendidikan Nasional, 2010).

Adapun seorang pendidik yang sukses apabila memiliki kepribadian yang kuat, mampu mengubah perilaku, sikap dan kebiasaan buruk peserta didik menjadi sikap yang baik. Kepribadian merupakan poin yang penting dalam memahami sisi lain dari tugasnya tidak saja sebagai seorang pengajar melainkan sebagai seorang pendidik. Oleh karena itu, untuk mewujudkan hal tersebut maka ada beberapa langkah yang ditempuh antara lain dosen memberikan contoh sikap dan perilaku yang baik di dalam kelas, terbuka dalam menerima pendapat, saran dan kritik dari mahasiswa terhadap mata kuliah yang diajarkan serta mampu menciptakan suasana yang nyaman dan bersahabat selama perkuliahan.

Kompetensi pedagogik, profesionalisme dan kepribadian dirumuskan dalam bentuk instrumen pengukuran kinerja tenaga pendidik yang terdiri atas beberapa indikator pengukur kompetensi tersebut. Indikator-indikator ini akan diisi oleh mahasiswa pada pertengahan semester dan akhir semester. Selanjutnya akan dianalsis dengan tujuan untuk mengevaluasi kualitas instrumen yang digunakan di STMIK Bumigora Mataram. Hasil evaluasinya digunakan untuk menemukan solusi jika terjadi perbaikan dalam proses pembelajaran. 
Hasanah, U., Putrawangsa, S., \& Ardi, R. (2017). EVALUASI KUALITAS INSTRUMEN PENGUKURAN KINERJA TENAGA PENDIDIK. JURNAL TATSQIF, 15(1). Retrieved from http://ejurnal.iainmataram.ac.id/ index.php/tatsqif/article/view/1310

\section{METODE}

1. Desain Penelitian

Metode kuantitatif dengan pendekatan survey dilakukan untuk mengevaluasi instrumen pengukur kinerja pendidik. Instrumen ini terdiri atas beberapa indikator pengukur variabel kompetensi pedagogik, dari indikator pengukur variabel pedagogik, profesionalisme dan kepribadian. Hasil analisis berdasarkan hasil simulasi dari SPSS dengan mereduksi data.

\section{Teknik Pengambilan Data}

Pengambilan data dilakukan secara random sebanyak 537 mahasiswa Informatika STMIK Bumigora Mataram program studi Strata 1 Teknik Informatika, D3 Teknik Informatika dan D3 Manajemen Informatika pada Semester Ganjil tahun ajaran 2015/2016. Secara keseluruhan total mahasiswa 1200 sehingga dapat disimpulkan bahwa dari jumlah sampel 537 mahasiswa dapat mewakili populasi dengan taraf signifikan 0.5.

3. Analisis Data

Data dianalisis secara statistik menggunakan analisis faktor (Factor Analysis) merupakan prosedur analisis yang digunakan untuk data reduction atau summarization atau mereduksi dimensi (Widayat, __). Teknik analisis data ini digunakan untuk menguji hubungan sekumpulan variabel, mengidendentifikasi underlying dimensions (factors) yang dapat menjelaskan korelasi sekumpulan variabel. Kegunaan lainnya, untuk mengidentifikasi variabel baru yang dapat digunakan untuk analisis lainnya, mengidentifikasi satu atau beberapa variabel dari variabel yang banyak jumlahnya dan mengkonfirmasi konstruk suatu variabel. Data ini dianalisis menggunakan perangkat lunak SPSS yang teridiri atas beberapa tahap yaitu:
a. Formulasi Problem
b. Menyusun matrik korelasi
c. Menentukan prosedur analisis 
Hasanah, U., Putrawangsa, S., \& Ardi, R. (2017). EVALUASI KUALITAS INSTRUMEN PENGUKURAN KINERJA TENAGA PENDIDIK. JURNAL TATSQIF, 15(1). Retrieved from http://ejurnal.iainmataram.ac.id/ index.php/tatsqif/article/view/1310
d. Mengekstrasi faktor (Extracting Factors)
e. Merotasi faktor (Rotating Factors)
f. Interpretasi

4. Indikator Pengukur Instrumen Kinerja Pendidik

Indikator pengukur kinerja pendidik yang dievaluasi dalam penelitian ini dikelompokkan dalam tiga komponen berikut yaitu:

a. Indikator pengukur Paedagogik

Tabel 1.

Indikator Pengukur Paedagogik

\begin{tabular}{|l|l|l|}
\hline No & Uraian & Kode \\
\hline 1 & $\begin{array}{l}\text { Dosen menguasai materi yang diajarkan serta dapat } \\
\text { menyampaikan dan menjelaskan dengan baik di depan kelas. }\end{array}$ & P1 \\
\hline 2 & $\begin{array}{l}\text { Penjelasan dosen dapat diterima dan dipahami dengan baik } \\
\text { dan jelas oleh mahasiswa }\end{array}$ & P2 \\
\hline 3 & Dosen mampu membimbing dan memotivasi mahasiswa & P3 \\
\hline 4 & $\begin{array}{l}\text { Dosen memberikan umpan balik dan membahas tiap tugas / } \\
\text { quis / ujian setelah dikumpulkan. }\end{array}$ & P4 \\
\hline 5 & $\begin{array}{l}\text { Dosen dalam kegiatan belajar mengajar, menyertakan alat / } \\
\text { bahan bantu pengajaran (contoh : slide \& proyektor / alat } \\
\text { peraga / bahan pustaka / material belajar) }\end{array}$ & P5 \\
\hline
\end{tabular}

b. Indikator pengukur Profesionalisme

Tabel 2.

Indikator Pengukur Profesionalisme

\begin{tabular}{|l|l|l|}
\hline No & Uraian & Kode \\
\hline 1 & $\begin{array}{l}\text { Dosen mengajar tepat waktu saat masuk kelas dan tepat } \\
\text { waktu saat selesai belajarnya, sesuai dengan jadwal yang } \\
\text { telah disepakati / ditetapkan. }\end{array}$ & PR1 \\
\hline 2 & $\begin{array}{l}\text { Pada pertemuan pertama dosen menjelaskan tentang pokok- } \\
\text { pokok materi kuliah, metode pembelajaran dan sistem } \\
\text { penilaian hasil belajar }\end{array}$ & PR2 \\
\hline 3 & $\begin{array}{l}\text { Pada pertemuan pertama dosen menjelaskan hasil akhir yang } \\
\text { ingin dicapai dari mengikuti mata kuliah berikut tentang } \\
\text { aplikasi atau manfaat materi kuliah. }\end{array}$ & PR3 \\
\hline 4 & $\begin{array}{l}\text { Dosen menjelaskan keterkaitan bidang / topik yang diajarkan } \\
\text { dengan bidang/topik lain di luar mata kuliah }\end{array}$ & PR4 \\
\hline 5 & \begin{tabular}{l} 
Dosen memberikan contoh yang sesuai dengan materi yang \\
\hline
\end{tabular} & PR5 \\
\hline
\end{tabular}


Hasanah, U., Putrawangsa, S., \& Ardi, R. (2017). EVALUASI KUALITAS INSTRUMEN PENGUKURAN KINERJA TENAGA PENDIDIK. JURNAL TATSQIF, 15(1). Retrieved from http://ejurnal.iainmataram.ac.id/ index.php/tatsqif/article/view/1310

\begin{tabular}{|c|c|c|}
\hline & diajarkan & \\
\hline 6 & $\begin{array}{l}\text { Dosen menguasai isu-isu mutahir yang terkait dengan materi } \\
\text { yang diajarkan }\end{array}$ & PR6 \\
\hline 7 & $\begin{array}{l}\text { Dosen menjelaskan penerapan bidang/topik yang diajarkan } \\
\text { dengan kebutuhan dunia nyata }\end{array}$ & PR7 \\
\hline 8 & $\begin{array}{l}\text { Dosen memberikan kesempatan tanya jawab dan diskusi } \\
\text { atau studi kasus sesuai dengan materi yang diajarkan }\end{array}$ & PR8 \\
\hline 9 & $\begin{array}{l}\text { Dosen memberikan Soal ujian sesuai dengan isi materi } \\
\text { belajar yang telah dibahas dalam kegiatan perkuliahan. }\end{array}$ & PR9 \\
\hline 10 & $\begin{array}{l}\text { Dosen memberikan peniaian yang adil dan transparan, dan } \\
\text { selalu mengembalikan berkas jawaban ujian yang telah } \\
\text { dikoreksi, serta memberikan kesempatan mahasiswa untuk } \\
\text { menyampaikan keberatan apabila ada kesalahan penilaian } \\
\text { oleh dosen }\end{array}$ & PR10 \\
\hline 11 & $\begin{array}{l}\text { Apakah dosen dapat membuat anda bisa memahami dan } \\
\text { menguasai mata kuliah, serta dapat mengembangkan ilmu } \\
\text { pada mata kuliah ini secara mandiri }\end{array}$ & PR11 \\
\hline
\end{tabular}

c. Indikator pengukur Kepribadian

Tabel 3

Indikator Pengukur Kepribadian

\begin{tabular}{|l|l|l|}
\hline No & Uraian & Kode \\
\hline 1 & $\begin{array}{l}\text { Dosen memberikan contoh sikap dan prilaku yang baik di } \\
\text { dalam kelas }\end{array}$ & K1 \\
\hline 2 & $\begin{array}{l}\text { Dosen terbuka dalam menerima pendapat, saran dan kritik } \\
\text { dari mahasiswa terhadap mata kuliah yang diajarkan }\end{array}$ & K2 \\
\hline 3 & $\begin{array}{l}\text { Dosen mampu menciptakan suasana yang nyaman dan } \\
\text { bersahabat selama perkuliahan }\end{array}$ & K3 \\
\hline
\end{tabular}

\section{HASIL DAN PEMBAHASAN}

Pedagogik, profesionalisme dan kepribadian merupakan variabel yang dimasukkan dalam instrumen kinerja pendidik yang tidak bisa diukur secara langsung. Oleh karena itu, secara struktural ketiga variabel tersebut disebut dengan variabel laten dan untuk mengukurnya diperlukan beberapa indikator pengukur yang sesuai dengan variabel pedagogik, profesionalisme dan kepribadian. 
Hasanah, U., Putrawangsa, S., \& Ardi, R. (2017). EVALUASI KUALITAS INSTRUMEN PENGUKURAN KINERJA TENAGA PENDIDIK. JURNAL TATSQIF, 15(1). Retrieved from http://ejurnal.iainmataram.ac.id/ index.php/tatsqif/article/view/1310

\section{Indikator Pengukur Instrumen Kinerja Pendidik}

Analisis faktor tidak dimaksudkan untuk membuat prediksi dari suatu variabel melainkan untuk menemukan hubungan dan kekuatannya diantara semua bagian variabel. Dalam hal ini, variabel yang akan dianalisis adalah variabel pedagogik, profesionalisme dan kepribadian pendidik. Variabel pedagogik diukur dengan lima indikator yang dinotasikan dengan P1, P2, P3, P4 dan P5. Variabel profesionalisme diukur dengan 11 indikator dan dinotasikan dengan PR1, PR2, PR3, PR4, PR5, PR6, PR7, PR8, PR9, PR10, dan PR11. Sedangkan variabel kepribadian diukur oleh 3 indikator dan dinotasikan dengan K1, K2 dan K3.

\section{Uji Asumsi Analisis Faktor}

Ada beberapa asumsi yang harus dipenuhi dalam analisis faktor yaitu asumsi matrik korelasi pada KMO dan MSA. Asumsi ini dianalisis bertujuan untuk melihat korelasi antar variabel yang diukur dengan besaran nilai khususnya pada Correlation Matrix KMO dan Bartlett's Test of Sphericity atau Measure Sampling Adequacy (MSA) yang lebih besar dari 0,5 (Singgih, 2006). Oleh sebab itu, pengujian ini mengaharuskan adanya korelasi yang signifikan di antara paling sedikit beberapa variabel. Adapun hasil analisis data yang dilakukan diperoleh:

Tabel 4.

Nilai KMO dan Bartlett's Test

\begin{tabular}{|l|l|r|}
\hline \multicolumn{2}{|l|}{ Kaiser-Meyer-Olkin Measure of Sampling Adequacy } & 0.961 \\
\hline \multirow{3}{*}{ Bartlett's Test of Sphericity } & Approx. Chi-Square & 6505.407 \\
\cline { 2 - 3 } & Df & 171 \\
\cline { 2 - 3 } & Sig. & 0.000 \\
\hline
\end{tabular}

Berdasarkan Tabel 4 diatas dapat disimpulkan bahwa nilai KMO dan Bartlett's Test untuk korelasi antarvariabel lebih besar dari 0,5 (nilai KMO = 0,961) dengan signifikansi 0.000 (Santoso, 2000). Sedangkan untuk nilai Measures of Sampling Adequacy (MSA) setiap variabel lebih besar dari 0.5, 
Hasanah, U., Putrawangsa, S., \& Ardi, R. (2017). EVALUASI KUALITAS INSTRUMEN PENGUKURAN KINERJA TENAGA PENDIDIK. JURNAL TATSQIF, 15(1). Retrieved from http://ejurnal.iainmataram.ac.id/ index.php/tatsqif/article/view/1310

artinya semua variabel yang digunakan masih bisa diprediksi dan dianalisis lebih lanjut dengan rincian sebagai berikut:
a. $\mathrm{P} 1=0.955$
a. $\mathrm{PR} 1=0.969$
a. $\mathrm{K} 1=0.958$
b. $\mathrm{P} 2=0.922$
b. $\quad$ PR2 $=0.954$
b. $\mathrm{K} 2=0.953$
c. $\mathrm{P} 3=0.948$
c. $\mathrm{PR} 3=0.959$
c. $\mathrm{K} 3=0.960$
d. $\quad P 4=0.967$
d. $\quad P R 4=0.964$
e. $\mathrm{P} 5=0.972$
e. $\quad \mathrm{PR} 5=0.970$
f. $\quad$ PR6 $=0.964$
g. $\quad$ PR7 $=0.964$
h. $\mathrm{PR} 8=0.972$
i. $\quad$ PR9 $=0.969$
j. $\quad$ PR10 $=0.962$
k. $\quad$ PR11 $=0.964$

Berdasarkan hasil rincian di atas diperoleh nilai MSA $>0$ sehingga seluruh variabel indepedenden dapat dianalisis lebih lanjut.

\section{Pengelompokan Faktor}

Pengelompokan faktor dilakukan untuk menentukan variabel independen terbagi ke dalam satu atau beberapa faktor. Sebelumnya, 19 indikator ini dianalisis kemampuannya dalam mengukur kinerja tenaga pendidik di perguruan tinggi. Penjelasan variabel oleh faktor dapat dilihat pada Tabel 5 berikut ini:

Tabel 5.

Extraction Method: Principal Component Analysis

\begin{tabular}{|l|l|l|l|l|l|}
\hline & Extraction & & Extraction & & Extraction \\
\hline P1 & 0.613 & PR1 & 0.557 & PR8 & 0.602 \\
\hline P2 & 0.799 & PR2 & 0.649 & PR9 & 0.655 \\
\hline P3 & 0.674 & PR3 & 0.614 & PR10 & 0.567 \\
\hline P4 & 0.609 & PR4 & 0.494 & PR11 & 0.659 \\
\hline P5 & 0.560 & PR5 & 0.690 & K1 & 0.583 \\
\hline & & PR6 & 0.641 & K2 & 0.601 \\
\hline
\end{tabular}


Hasanah, U., Putrawangsa, S., \& Ardi, R. (2017). EVALUASI KUALITAS INSTRUMEN PENGUKURAN KINERJA TENAGA PENDIDIK. JURNAL TATSQIF, 15(1). Retrieved from http://ejurnal.iainmataram.ac.id/ index.php/tatsqif/article/view/1310

\begin{tabular}{|l|l|l|l|l|l|}
\hline & & PR7 & 0.614 & K3 & 0.578 \\
\hline
\end{tabular}

Tabel 5 menunjukkan bahwa nilai faktor P1 sebesar 0.613 atau 61,3\%, artinya faktor P1 secara 61,3\% mampu mengukur variabel pedagogik yaitu dosen menguasai materi yang diajarkan serta dapat menyampaikan dan menjelaskan dengan baik di depan kelas, merupakan pengukur kinerja pedagogik sebesar 61,3\%. Serupa dengan faktor lainnya yaitu P2 (penjelasan dosen dapat diterima dan dipahami dengan baik dan jelas oleh mahasiswa) mengukur pedagogik sebesar 79.9\%. Sedangkan P3 (Dosen mampu membimbing dan memotivasi mahasiswa) mengukur pedagogik sebesar $67.4 \%$ dan seterusnya. Tabel 5 menunjukkan rata-rata penjelasan faktor dalam instrumen kinerja pendidik diatas 50\% sehingga dapat disimpulkan bahwa faktor tetap akan ditentukan.

\section{Menyusun Nilai Eigen}

Dari 19 indikator dalam instrumen diperoleh nilai eigen yang akan digunakan untuk melihat pembagian komponen faktornya yang ditandai dengan nilai eigen lebih besar dari 1 seperti yang terlihat pada Tabel 6 di bawah ini:

Tabel 6.

Total Variance Explained

\begin{tabular}{|c|c|c|c|}
\hline \multirow{2}{*}{ Component } & \multicolumn{3}{|c|}{ Initial Eigenvalue } \\
\cline { 2 - 4 } & Total & \% of Variance & Cumulative \% \\
\hline 1 & 10.638 & 55.990 & 55.990 \\
\hline 2 & 1.120 & 5.893 & 61.884 \\
\hline
\end{tabular}

Tabel 6 menunjukkan bahwa terdapat dua komponen faktor yang terbentuk dari 19 indikator yang ada. Hal ini ditandai dengan dua komponen tersebut memiliki nilai eigen lebih besar dari 1 dan lainnya di bawah nilai standar (< 1). Oleh sebab itu, kedua komponen tersebut dapat dikelompokkan sebagai berikut:

Tabel 7. Rotated Component Matrix 
Hasanah, U., Putrawangsa, S., \& Ardi, R. (2017). EVALUASI KUALITAS INSTRUMEN PENGUKURAN KINERJA TENAGA PENDIDIK. JURNAL TATSQIF, 15(1). Retrieved from http://ejurnal.iainmataram.ac.id/ index.php/tatsqif/article/view/1310

\begin{tabular}{|l|c|c|l|c|c|l|c|c|}
\hline \multirow{2}{*}{} & \multicolumn{2}{|c|}{ Component } & \multirow{2}{*}{} & \multicolumn{2}{c|}{ Component } & & \multicolumn{2}{c|}{ Component } \\
\cline { 2 - 3 } \cline { 5 - 6 } & $\mathbf{1}$ & $\mathbf{2}$ & & $\mathbf{1}$ & $\mathbf{2}$ & & $\mathbf{1}$ & $\mathbf{2}$ \\
\hline P1 & 0.329 & 0.710 & PR4 & 0.497 & 0.497 & K1 & 0.661 & 0.382 \\
\hline P2 & 0.166 & 0.878 & PR5 & 0.753 & 0.350 & K2 & 0.646 & 0.429 \\
\hline P3 & 0.315 & 0.758 & PR6 & 0.631 & 0.493 & K3 & 0.398 & 0.648 \\
\hline P4 & 0.520 & 0.582 & PR7 & 0.616 & 0.484 & & & \\
\hline P5 & 0.712 & 0.232 & PR8 & 0.664 & 0.401 & & & \\
\hline PR1 & 0.714 & 0.217 & PR9 & 0.731 & 0.347 & & & \\
\hline PR2 & 0.772 & 0.230 & PR10 & 0.631 & 0.411 & & & \\
\hline PR3 & 0.701 & 0.351 & PR11 & 0.482 & 0.653 & & & \\
\hline
\end{tabular}

Tabel 7 menunjukkan pembagian indikator terbagi menjadi dua komponen dengan uraian sebagai beikut:

a. Komponen 1 terdiri atas P4, P5, PR1,PR2,PR3, PR5, PR6, PR7, PR8, PR9, PR10, K1 dan K2

b. Komponen 2 terdiri atas P1, P2, P3, P4, PR11, dan K3

\section{Interpretasi}

Berdasarkan hasil analisis pada Tabel 7 di atas dapat disimpulkan bahwa dari 19 indikator terbagi menjadi dua faktor untuk mengevaluasi instrumen pengukur kinerja tenaga pendidik di perguruan tinggi yang akan diisi oleh mahasiswa yaitu faktor formal dan informal. Faktor formal yaitu faktor yang bersifat institusional, resmi dan terstruktur. Sedangkan faktor informal bersifat noninstruksional artinya faktor ini terjadi berdasarkan emosional mahasiswa. Adapun faktor formal terdiri atas 12 indikator yaitu:

Tabel 8.

Faktor Formal

\begin{tabular}{|l|l|l|l|}
\hline No & Kode & Uraian Indikator & Bobot \\
\hline 1 & PR2 & $\begin{array}{l}\text { Pada pertemuan pertama dosen menjelaskan tentang } \\
\text { pokok-pokok materi kuliah, metode pembelajaran dan } \\
\text { sistem penilaian hasil belajar }\end{array}$ & 0.772 \\
\hline 2 & PR5 & $\begin{array}{l}\text { Dosen memberikan contoh yang sesuai dengan materi } \\
\text { yang diajarkan }\end{array}$ & 0.753 \\
\hline
\end{tabular}


Hasanah, U., Putrawangsa, S., \& Ardi, R. (2017). EVALUASI KUALITAS INSTRUMEN PENGUKURAN KINERJA TENAGA PENDIDIK. JURNAL TATSQIF, 15(1). Retrieved from http://ejurnal.iainmataram.ac.id/ index.php/tatsqif/article/view/1310

\begin{tabular}{|c|c|c|c|}
\hline 3 & PR9 & $\begin{array}{l}\text { Dosen memberikan Soal ujian sesuai dengan isi materi } \\
\text { belajar yang telah dibahas dalam kegiatan perkuliahan. }\end{array}$ & 0.731 \\
\hline 4 & PR1 & $\begin{array}{l}\text { Dosen mengajar tepat waktu saat masuk kelas dan tepat } \\
\text { waktu saat selesai belajarnya, sesuai dengan jadwal yang } \\
\text { telah disepakati / ditetapkan. }\end{array}$ & 0.714 \\
\hline 5 & P5 & $\begin{array}{l}\text { Dosen dalam kegiatan belajar mengajar, menyertakan } \\
\text { alat / bahan bantu pengajaran (contoh : slide \& } \\
\text { proyektor / alat peraga / bahan pustaka / material } \\
\text { belajar) }\end{array}$ & 0.712 \\
\hline 6 & PR3 & $\begin{array}{l}\text { Pada pertemuan pertama dosen menjelaskan hasil akhir } \\
\text { yang ingin dicapai dari mengikuti mata kuliah berikut } \\
\text { tentang aplikasi atau manfaat materi kuliah. }\end{array}$ & 0.701 \\
\hline 7 & PR8 & $\begin{array}{l}\text { Dosen memberikan kesempatan tanya jawab dan } \\
\text { diskusi atau studi kasus sesuai dengan materi yang } \\
\text { diajarkan }\end{array}$ & 0.664 \\
\hline 8 & K1 & $\begin{array}{l}\text { Dosen memberikan contoh sikap dan prilaku yang baik } \\
\text { di dalam kelas }\end{array}$ & 0.661 \\
\hline 9 & K2 & $\begin{array}{l}\text { Dosen terbuka dalam menerima pendapat, saran dan } \\
\text { kritik dari mahasiswa terhadap mata kuliah yang } \\
\text { diajarkan }\end{array}$ & 0.646 \\
\hline 10 & PR6 & $\begin{array}{l}\text { Dosen menguasai isu-isu mutahir yang terkait dengan } \\
\text { materi yang diajarkan }\end{array}$ & 0.631 \\
\hline 11 & PR10 & $\begin{array}{l}\text { Dosen memberikan peniaian yang adil dan transparan, } \\
\text { dan selalu mengembalikan berkas jawaban ujian yang } \\
\text { telah dikoreksi, serta memberikan kesempatan } \\
\text { mahasiswa untuk menyampaikan keberatan apabila ada } \\
\text { kesalahan penilaian oleh dosen }\end{array}$ & 0.631 \\
\hline 12 & PR7 & $\begin{array}{l}\text { Dosen menjelaskan penerapan bidang/topik yang } \\
\text { diajarkan dengan kebutuhan dunia nyata }\end{array}$ & 0.616 \\
\hline
\end{tabular}

Tabel 9.

Faktor Informal

\begin{tabular}{|c|c|c|c|}
\hline No & Kode & Uraian Indikator & Bobot \\
\hline 1 & P2 & $\begin{array}{l}\text { Penjelasan dosen dapat diterima dan dipahami dengan } \\
\text { baik dan jelas oleh mahasiswa }\end{array}$ & 0.878 \\
\hline 2 & P3 & Dosen mampu membimbing dan memotivasi mahasiswa & 0.758 \\
\hline 3 & P1 & $\begin{array}{l}\text { Dosen menguasai materi yang diajarkan serta dapat } \\
\text { menyampaikan dan menjelaskan dengan baik di depan } \\
\text { kelas. }\end{array}$ & 0.710 \\
\hline 4 & PR11 & $\begin{array}{l}\text { Apakah dosen dapat membuat anda bisa memahami dan } \\
\text { menguasai mata kuliah, serta dapat mengembangkan } \\
\text { ilmu pada mata kuliah ini secara mandiri }\end{array}$ & 0.653 \\
\hline 5 & K3 & Dosen mampu menciptakan suasana yang nyaman dan & 0.648 \\
\hline
\end{tabular}


Hasanah, U., Putrawangsa, S., \& Ardi, R. (2017). EVALUASI KUALITAS INSTRUMEN PENGUKURAN KINERJA TENAGA PENDIDIK. JURNAL TATSQIF, 15(1). Retrieved from http://ejurnal.iainmataram.ac.id/ index.php/tatsqif/article/view/1310

\begin{tabular}{|l|l|l|l|}
\hline & & bersahabat selama perkuliahan & \\
\hline 6 & P4 & $\begin{array}{l}\text { Dosen memberikan umpan balik dan membahas tiap } \\
\text { tugas /quis/ujian setelah dikumpulkan. }\end{array}$ & 0.582 \\
\hline
\end{tabular}

Indikator PR4 (Dosen menjelaskan keterkaitan bidang/topik yang diajarkan dengan bidang/topik lain di luar mata kuliah) dihilangkan karena memiki nilai eigen lebih kecil dari 0.5 (PR4 $=0.497)$ dan memiliki makna yang sama dengan indikator PR7 (Dosen menjelaskan penerapan bidang/topik yang diajarkan dengan kebutuhan dunia nyata).

\section{SIMPULAN}

Hasil evaluasi instrumen pengukur kinerja pendidik terbagi menjadi dua komponen yaitu faktor formal terdiri atas 12 indikator yaitu secara berurutan PR2, PR5, PR9, PR1, P5, PR3, PR8, K1, K2, PR6, PR10 dan PR7 dan faktor informal yang terdiri atas 6 indikator yaitu secara berurutan P2, P3, P1, PR11, K3 dan P4. Untuk indikator PR4 dihilangkan karena memiliki nilai eigen lebih kecil dari 0.5 dan memiliki makna yang sama dengan PR7. Sehingga dapat disimpulkan bahwa instrumen kinerja pendidik di lingkungan STMIK Bumigora Mataram diukur dengan 18 indikator saja.

\section{UCAPAN TERIMA KASIH}

Terima kasih kami ucapkan kepada pihak Badan Penjamin Mutu di lingkungan STMIK Bumigora Mataram yang telah memberikan data untuk kelancaran penyusunan artikel yang berkaitan dengan instrumen pengukur kinerja pendidik di perguruan tinggi.

\section{DAFTAR PUSTAKA}

Departemen Pendidikan Nasional.(2008).Penilaian Kinerja Guru.

Hary Susanto. (2012). Faktor-Faktor yang Mempengaruhi Kinerja Guru Sekolah Menengah Kejuruan. Jurnal Pendidikan Vokasi, Vol. 2, Nomor 2, Juni 2012. 
Hasanah, U., Putrawangsa, S., \& Ardi, R. (2017). EVALUASI KUALITAS INSTRUMEN PENGUKURAN KINERJA TENAGA PENDIDIK. JURNAL TATSQIF, 15(1). Retrieved from http://ejurnal.iainmataram.ac.id/ index.php/tatsqif/article/view/1310

Kementerian Pendidikan Nasional. (2010). Pedoman Pelaksanaan Penilaian Kinerja Guru (PK Guru). Jakarta: Direktorat Jenderal Peningkatan Mutu Pendidik dan Tenaga Kependidikan.

Mitchell, T. R, \& Larson, J. R., jr., (1987). People in organizations, an instruduction to organizational behavior ( $3^{\text {th }}$ ed). Singapure: Mc Graw Hill Book Company.

Santoso, Singgih. (2006). Seri Solusi Bisnis Berbasis TI: Menggunakan SPSS untuk Statistik Multivariat. Jakarta: Elex Media Komputindo.

Tim Penyusun STMIK Bumigora Mataram.(2015).Kebijakan SPMI STMIK Bumigora Mataram.

Widayat. (2016). Analisis Faktor (Factor Analysis), Bahan Pelatihan Statistika. 